\title{
Chronic Migraine: Burden, Comorbidities, and Treatment
} Kronik Migren: Hastalık Yükü, Komorbidite ve Tedavi

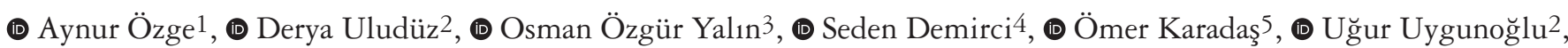
(1) Aksel Siva ${ }^{2}$

\author{
${ }^{1}$ Mersin University Faculty of Medicine, Department of Neurology, Mersin, Turkey \\ 2Istanbul University Cerrahpasa Faculty of Medicine, Department of Neurology, Istanbul, Turkey \\ ${ }^{3}$ Health Sciences University, Istanbul Training and Research Hospital, Clinic of Neurology, Istanbul, Turkey \\ ${ }^{4}$ Isparta Suleyman Demirel University Faculty of Medicine, Department of Neurology, Isparta, Turkey \\ 5University of Health Sciences, Gulhane Training and Research Hospital, Clinic of Neurology, Ankara, Turkey
}

\begin{abstract}
Chronic migraine (CM) is defined as headache occurring on 15 or more days per month for more than three months, which, on at least 8 days per month, has the features of migraine headache. In the International Classification of Headache Disorders, CM is defined as a separate entity and the presence of drug overuse headache is removed from being an exclusion criterion. CM accounts for more than $10 \%$ of all migraine patients and includes the group with the most prominent disease-related disability. Diagnosis is often overlooked and most patients do not receive appropriate treatment. CM is associated with social and economic burdens such as frequent use of health services, drug overuse, and significant disruption to work and school life. Compared with episodic migraine, more frequent comorbid disorders are important in migraine chronicity, treatment, and course. With appropriate treatment in CM, it is possible to increase the quality of life of the patient and to reduce the social economic burden associated with migraine. In this review, the disease burden of CM, accompanying comorbid diseases, and current treatment options are reviewed.
\end{abstract}

Keywords: Chronic migraine, CM, comorbidity, disease burden, treatment

\section{$\ddot{O} \mathbf{z}$}

Kronik migren (KM) ayda 15 gün ve daha sık görülen baș ağrılarının 3 aydan uzun süredir devam etmesi ve 8 veya daha fazla gün baş ağrısının migren özellikleri taşıması ile tanımlanmaktadır. Uluslararası Baş Ağrısı Sınıflandırması’nda KM ayrı bir antite olarak tanımlanmış ve ilaç aşırı kullanımı baş ağrısı varlı̆̆ı bir dışlama kriteri olmaktan çıkarılmıştır. KM tüm migren hastalarının \%10'dan fazlasını oluşturmaktadır ve hastalık ilişkili özürlülüğün en belirgin olduğu grubu içermektedir. Tanı sıklıkla atlanmakta ve çoğu hasta uygun tedavi almamaktadır. KM sağlık hizmetlerinin sık kullanımı, ilaç aşırı kullanımı, iş ve okul hayatında belirgin aksama gibi sosyal ve ekonomik yük ile ilişkilidir. Epizodik migren ile karşılaştırıldı̆̆ında daha sık gözlenen komorbid bozukluklar migren kronikleşmesinde, tedavisinde ve seyrinde önemlidir. KM'de uygun tedavi ile hastanın yaşam kalitesinde artış ve migren ilişkili toplumsal ekonomik yükün azaltılması sağlanabilir. Bu derlemede KM'nin hastalık yükü, eşlik eden komorbid hastalıklar ve güncel tedavi seçenekleri gözden geçirilmiştir.

Anahtar Kelimeler: Kronik migren, KM, komorbidite, hastalık yükü, tedavi

\section{Introduction}

Migraine is a neurologic disorder characterized by frequent recurrent, throbbing headache episodes and accompanying symptoms, and it is associated with significant loss in quality of life and workforce. The diagnosis is based on the International
Classification of Headache Disorders (ICHD-3 beta) diagnostic criteria published in 2013. Chronic migraine (CM) is defined as a separate entity in the final classification by the fact that it has unique pathophysiologic features, and drug overuse was removed from the exclusion criteria in the recently published diagnostic

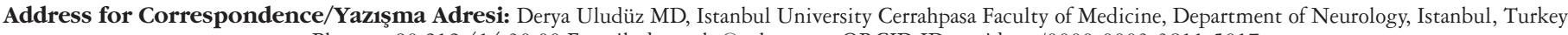
Phone: +90 2124143000 E-mail: deryaulu@yahoo.com ORCID ID: orcid.org/0000-0003-3811-5017

Received/Geliş Tarihi: 09.07.2017 Accepted/Kabul Tarihi: 16.08.2017

${ }^{\circledR}$ Copyright 2018 by Turkish Neurological Society

Turkish Journal of Neurology published by Galenos Publishing House. 
criteria (1). The presence of headache occurring on 15 or more days per month for more than three months, which, on at least 8 days per month, has the features of migraine headache is defined as CM. It is estimated that CM is present in $1-3 \%$ of the population and accounts for more than $10 \%$ of all migraineurs $(2,3,4)$. In a community-based study conducted by Ertas et al. (5) in our country in 2012, the prevalence of migraine was found as $16.4 \%$, and the prevalence of CM was $1.7 \%$ when patients with drug overuse were included. CM involves patients with the most significant headache-related disability, loss of workforce, drug overuse, and deterioration in quality of life (2). The diagnosis of this condition is often overlooked throughout the world and most patients do not receive appropriate treatment. In this review, CM disease burden, comorbid diseases, and current treatment options are discussed.

\section{Chronic Migraine Disease Burden}

$\mathrm{CM}$ is responsible for about $1 \%$ of all disability in the world and is among the major disability-causing diseases according to life-year-based evaluations (4). It is estimated that the cost of headache-related annual expenditure in the United States is 20 billion dollars and over 27 billion dollars in Europe $(6,7)$.

Headache attacks in CM negatively affect the work life, education, academic, and social life of the patient. Several studies with the standardized Migraine-Specific Quality of Life Questionnaire and Migraine Disability Assessment (MIDAS) questionnaire have shown that $\mathrm{CM}$ is associated with significant workforce loss $(5,8)$. In more than one quarter of patients, migraine-related disability is advanced and MIDAS scores are moderate-to-advanced at $90 \%$. More than $65 \%$ of patients with $\mathrm{CM}$ report that headache adversely affects their work lives, and also, over half of the patients' state that their working efficiency is significantly reduced on days with headaches (8).

In the International Burden of Migraine Study (IBMS), more than half $(57 \%)$ of the CM patients reported experiencing 5 days or more of occupational or school absenteeism during a three-month period, and $58 \%$ stated that they had difficulties in housework. The weekly work-time loss is 4.6 hours in migraine patients in $\mathrm{CM}$ and it is reported as 1.1 hours in rare episodic migraine (EM) (9).

\section{Comorbidity}

It is common for CM to be associated with disability and many comorbid diseases that adversely affect treatment response. The recognition and effective management of comorbidities have an important place in the treatment of migraine, especially in the case of CM $(10,11)$.

\section{Chronic Migraine and Comorbid Psychiatric Diseases}

Depression is the most frequent psychiatric comorbidity in CM (8.6-47.9\%) and the migraine-depression relation is bidirectional $(11,12,13)$. Migraine is associated with a 2.5fold increase in lifetime risk of depression. Depression is more frequently reported in patients with migraine with aura and CM, and depression is a well known risk factor for migraine chronicity.
Depression in $\mathrm{CM}$ is considered as a poor prognostic indicator $(14,15,16,17,18,19,20)$.

The close association between anxiety disorders and migraine has been shown in community-and clinically-based studies $(21,22,23,24)$. Generalized anxiety disorders, obsessive-compulsive disorder, and panic disorder are two-to-five times more common in CM $(16,19)$. Anxiety disorders are more frequent in CM than in EM (30.2\% and $18.8 \%$, respectively), and anxiety disorder is a risk factor for CM (23). Hypothalamic-pituitary-adrenal axis disorders, hormonal changes, serotonergic dysfunction, and psychogenic factors are the mechanisms proposed to explain the possible neurobiologic basis of the association between migraine and anxiety disorder $(18,19,20,21,22)$.

Bipolar disorder-migraine association is reported in young adults and it is suggested to be more common in cases with migraine with aura (24). Post-traumatic stress disorders are more common in CM patients, which may be associated with childhood neglect and abuse $(25,26,27)$. Tietjen et al. (28) emphasized that emotional abuse may be associated with CM and migraine chronicity.

\section{Neurologic Comorbidities}

When the sleep disturbances-migraine relation is examined, it is known that many sleep disorders including sleep apnea, restless legs syndrome, parasomnia and insomnia are frequent in migraine (29). In addition, sleep disorders are defined as independent risk factors for the chronicity of migraine. In CM, snoring, insomnia and daytime sleepiness are more frequent, and reduction in headache has been reported with behavioral sleep regulation (29,30,31).

There is conflicting information about the effect of epilepsymigraine comorbidity on migraine. While some studies have reported an increase in the frequency of migraine attacks in epilepsy patients, the relationship between the frequency of attacks and epilepsy has not been demonstrated in other studies $(32,33)$. Similar pathophysiologic mechanisms are suggested by the reason that both conditions are also channelopathies.

When vascular comorbidities are reviewed, migraine appears to be considered as a risk factor for ischemic stroke. Vascular risk factors such as hyperlipidemia and hypertension have been reported more frequently in CM. A community-based study reports that the risk of ischemic stroke is 1.7 times higher in patients with migraine with aura $(34,35,36,37)$. Migraine with aura has also been associated with an increased risk of myocardial infarction and transient ischemic attack (37). Body mass index in CM is higher than in patients with EM, and obesity is also identified as an independent risk factor for migraine chronicity $(38,39,40,41)$.

Rose et al. (42) reported a 3 -fold increase in angina risk in a 10 -year follow-up study in migraine patients with aura. No high risk for coronary artery disease was reported in the same study. In the Women's Health study, migraine with aura was found to be associated with ischemic stroke and increased risk for all cardiovascular diseases (41). Buse et al. (4) reported a higher risk of heart disease / angina and stroke in patients with CM compared with patients with episodic (OR: 1.4, OR: 1.7, respectively). It is also known that patent foramen ovale, atrial septal aneurysm and mitral valve prolapse are seen more frequently in patients with migraine than healthy populations $(41,42,43,44,45)$. 
The relationship between the majority of chronic pain syndromes and migraine, especially $\mathrm{CM}$, is well known. It is reported that this association is observed twice as frequently in $\mathrm{CM}$ and that more than $30 \%$ of $\mathrm{CM}$ patients have back-neck pain, arthritis and joint pain (46). In explaining the comorbidity of painful syndromes, abnormalities of the pain matrix, which involves the cortical and subcortical areas responsible for pain processing, is held responsible rather than a specific pain locus (47).

It has been shown that nearly half of all patients with fibromyalgia have migraine and that fibromyalgia accompanies migraine in $16-35 \%$ of patients (48).

When other comorbid disorders are examined, it is seen that patients with migraine are at increased risk for chronic bronchitis and asthma-related symptoms. Özge et al. (49) reported that atopic diseases were 1.7 times more frequently observed in children with migraine with aura. Studies have shown that irritable bowel syndrome is 1.6 times more frequent in migraineurs, that there is increased risk of celiac disease in children and adolescents with migraine, and that chronic fatigue syndrome and vasculitis are more frequent $(50,51)$. There are a number of studies investigating the association of migraine with bruxism and temporomandibular dysfunction (TMD). Temporomandibular dysfunction is thought to be a risk factor for the presence of chronic daily headache $(52,53)$.

\section{Treatment Approaches}

In ICHD-3 beta, CM is defined as ongoing frequent headache attacks for 3 months or longer (1). Although a definite time interval in the definition of the disease is very important in terms of standardization in scientific studies, it is important to evaluate prognostic markers in addition to the temporal profile of chronic pain. Assessment and treatment of chronicity-related comorbidities also constitute the basis of CM treatment $(54,55)$. The management of accompanying psychiatric disorders, sleep disturbances, and stress can lead to the conversion of CM into an episodic form, as well as preventing many patients with EM from chronification.

Realistic determination of treatment goals in CM, introducing a temporal profile of treatment expectancy, and sharing this strategy with patient are among the important steps in the treatment (55). Treatment should include reduction of headache frequency, severity and progression, reduction of migraine-related disability (loss of workforce or education), and correction of the deterioration in the patient's quality of life (2). Diagnosis of CM is quite easy for physicians who know the criteria and the disease, but it is important to evaluate the comorbidities and the variables that can lead to an increase in the frequency of pain. For this reason, it is essential to individualize the treatment, to carefully examine the comorbidities that can accompany, and to evaluate the patient in detail by the treating physician. In this article, we classified treatment strategies under three headings: (1) Behavioral therapies, (2) Pharmacological treatments, and (3) Interventional procedures.

\section{Behavioral Therapies}

Regulation of sleep and vital activities, avoidance of pain triggers: Sleep disorders are well known comorbid conditions associated with chronicity $(27,56)$. Sleep deprivation or hypersomnia is associated with both migraine attack triggers and chronicity. However, sleep disorders are a wide spectrum of diseases and careful anamnesis and history must be deepened. There may be sleep disturbances associated with the patient's lifestyle and habits (e.g., excessive daytime sleepiness, hypersomnia, daily alcohol intake, caffeine overuse, substance abuse).

Difficulty sleeping-maintaining and the associated diagnoses (e.g., sleep apnea syndrome, periodic leg movements, parasomnias) should be questioned carefully. As a result, it should be recommended to all patients that all factors negatively affecting sleep quality such as attention to sleep hygiene, avoidance of daytime sleep, regulation of bed times, excessive use of caffeine, and alcohol use should be corrected. Patient education, keeping the treatment expectations realistic, regular nutrition, increasing physical activity, abundant hydration, prevention and treatment of obesity, prevention of drug overuse should be offered to all patients. More systematic and researched approaches include relaxation techniques, biofeedback, cognitive behavioral treatments, but the effects have not been fully proven and the practice in clinical practice is challenging due to the need for special expertise $(57,58)$.

Avoidance of pain triggers should be recommended for all diseases, but it is important to note that a realistic plan can be drawn up that does not cause serious limitations in the life of the patient. Long trips, some social activities and environments can trigger many episodes in the patient, but the prohibition of a very long list can sometimes cause more disability in the life of the patient than CM. It is important to manage triggers that the patient enjoys; a strategy of accepting and coping rather than avoidance is important in improving quality of life $(57,59)$.

\section{Pharmacologic Treatments}

Prophylactic treatment options of CM have been studied less than EM. Existing controlled studies have methodologic inadequacies. These studies include serious methodologic differences such as small sample size, frequency of quitting study, coexistence of other prophylactic drugs, failure to determine the specific headache type, and the inclusion/exclusion of drug overuse patients. Pharmacologic agents with the most clinical experience in $\mathrm{CM}$ include beta-blockers, topiramate, and amitriptyline $(60,61,62,63)$.

In the presence of drug overuse in $\mathrm{CM}$, both headaches should be coded according to ICHD-3 beta diagnostic criteria. The first approach in the treatment of these patients is discontinuation of analgesic overuse. There is no consensus on whether this is going to be gradual or sudden, but we advise our patients to stop medicines suddenly. Inpatient treatment of these patients is often not possible in our country, and frequent visits are difficult to perform in everyday practice. Appropriate prophylactic treatment should be initiated by monitoring comorbidities in conjunction with drug withdrawal. Two agents with proven efficacy are topiramate and botulinum toxin (BoNT) injections, but other prophylactic agents may also be used in advance. The literature on steroid use as transitional treatment is also contradictory. An important element that can make a difference in treatment in resistant cases with $\mathrm{CM}$ and drug overuse is the multidisciplinary approach of disease management. In addition to the physician, treatment with a team 
of nurses, physiotherapists and psychologists with experience of headache is required.

Beta blockers (propranolol, timolol and metoprolol) are the first choice for migraine prophylaxis. Their efficacy has been demonstrated in migraine prophylaxis. Fatigue, sleep disturbances, depression, decrease in exercise tolerance, less frequently orthostatic hypotension, bradycardia and impotence are known side effects. They are contraindicated in the presence of congestive heart failure, asthma and insulin-dependent diabetes mellitus.

The efficacy of flunarizine, a calcium channel blocker, in migraine prophylaxis has been demonstrated in several studies. Flunarazin is effective at 5 and $10 \mathrm{mg}$ doses. Weight gain and depression are reported as adverse effects.

Valproic acid is seldom preferred with the adverse effect profile, but there is a controlled study showing efficacy (64). Valproic acid is effective at 500 and $1000 \mathrm{mg}$ doses. Weight gain, hair loss, and tremors in the hands are common adverse effects. Due to the fact that valproic acid is higly teratogenic, it should not be preferred as the first choice in women of childbearing age.

Topiramate appears to be the only prophylactic treatment that has been shown to be effective in the treatment of $\mathrm{CM}$ and drug overuse in randomized, placebo-controlled trials $(60,61,62)$. Topiramate has been reported to be effective at doses of more than $100 \mathrm{mg} /$ day. Behavioral and cognitive adverse effects, difficulty in finding words, weight loss, increase in intraocular pressure/blurred vision, numbness in hands and feet, and kidney stone formation are common adverse effects. In addition, it has a teratogenicity risk and may increase the frequency of cleft palate. For this reason, it should not be used as the first option in women of childbearing age.

Selective serotonin reuptake inhibitors and selective norepinephrine reuptake inhibitors are used empirically in the treatment of CM, but there are no data to support the use of these therapies in CM and chronic tension headaches $(65,66)$. Among antidepressants, amitriptyline has been reported to be effective at doses of $25,100 \mathrm{mg}$ in migraine prophylaxis. It can also be used in $\mathrm{CM}$ in a similar way. Dry mouth, sedation, weight gain are common adverse effects. Advanced age, heart rhythm disorder, prostate hypertrophy and urinary retention are contraindications.

In addition to treating $\mathrm{CM}$ as a specific entity, the diagnosis of comorbid diseases is also important in terms of treatment success. Our tertiary headache center experience supports that the regulation of triggers and the effective management of comorbid diseases after the diagnosis of CM are the core of the treatment. The information on treatments that can be applied by considering comorbidities in CM treatment is summarized in Table 1.

In CM, daily prophylactic medicines are not used regularly by most patients because of reasons such as patients' concerns about drugs, possible adverse effects, forgetting the medication, Social Security Institution based payment or problems with drug prescription. This leads to delays in treatment and deterioration in quality of life, as as well as economic burdens such significant workforce loss, unnecessary use of the health care system, and the use of chronic medication, and the problem is reaching serious size. Problems arising from the current SSI in our country also affect the regular medication use by patients and the medicine choices by clinicians. Topiramate, for example, is only covered on a monthly basis by a report for patients who are unresponsive to other treatment options.

\section{Interventional Treatments}

Although most patients benefit from medical treatments, lifestyle changes and behavioral treatment methods, patients who do not benefit from these treatment modalities constitute the refractory group. Patients with refractory headaches are probably the most intensely disabled group and their daily living activities are very much affected. In recent years, interventional methods have come to the fore in patients with refractory headache who have not responded to medical treatments.

\section{Botulinum Toxin Injection}

BoNT injections have become increasingly used in painful syndromes, particularly in neurology clinics, as the area of use that begins with movement disorders has expanded. BoNT application, which has a dramatic positive effect on medical treatment refractory $\mathrm{CM}$ cases, is frequently used in our clinical treatment practice. BoNT is a neurotoxin produced by Clostridium botulinum, a Grampositive anaerobic bacterium, and there are a total of 7 serotypes (A-G). The story of the BoNT-A serotype began with the discovery that acetylcholine release was reduced experimentally in 1949 and reached today through the studies done by ophthalmologists in 1960. Only type A (Botox ${ }^{\circledR}$, Dysport ${ }^{\circledR}$, Xeomin ${ }^{\circledR}$ and Prosigne ${ }^{\circledR}$ ) and type $\mathrm{B}\left(\mathrm{Myobloc}^{\circledR}\right)$ serotypes are available as commercial preparations in medical use. Botox ${ }^{\circledR}$ commercial preparation with proven efficacy in randomized controlled trials have been used for headache studies and have been licensed for CM diagnosis in many countries in 2010 .

\begin{tabular}{|c|c|c|}
\hline $\begin{array}{l}\text { Pharmacologic } \\
\text { approaches }\end{array}$ & Comorbidity & $\begin{array}{l}\text { Adverse effects and } \\
\text { contraindications }\end{array}$ \\
\hline Amitriptyline & $\begin{array}{l}\text { Depression, } \\
\text { anxiety, insomnia, } \\
\text { underweight }\end{array}$ & $\begin{array}{l}\text { Sleepiness, weight } \\
\text { gain, arrhythmia, } \\
\text { difficulty in urination }\end{array}$ \\
\hline Propranolol & $\begin{array}{l}\text { Anxiety disorder, } \\
\text { exam anxiety }\end{array}$ & $\begin{array}{l}\text { Weight gain, } \\
\text { depression, } \\
\text { bradycardia }\end{array}$ \\
\hline Topiramat* & Epilepsy, obesity & $\begin{array}{l}\text { Difficulty in word } \\
\text { finding, forgetfulness, } \\
\text { weight loss, kidney } \\
\text { stone }\end{array}$ \\
\hline $\begin{array}{l}\text { Duloxetine, } \\
\text { venlafaxine }^{* * *}\end{array}$ & $\begin{array}{l}\text { Depression, } \\
\text { anxiety disorders, } \\
\text { neuropathic pain }\end{array}$ & $\begin{array}{l}\text { Drowsiness, } \\
\text { sleepiness } \\
\text { Increase in blood } \\
\text { pressure, difficulty in } \\
\text { cessation of drug use }\end{array}$ \\
\hline Valproic acid ${ }^{* * *}$ & $\begin{array}{l}\text { Epilepsy, mood } \\
\text { disorders }\end{array}$ & $\begin{array}{l}\text { Weight gain, } \\
\text { hepatotoxicity, } \\
\text { pancytopenia, severe } \\
\text { teratogenicity risk }\end{array}$ \\
\hline \multicolumn{3}{|c|}{ 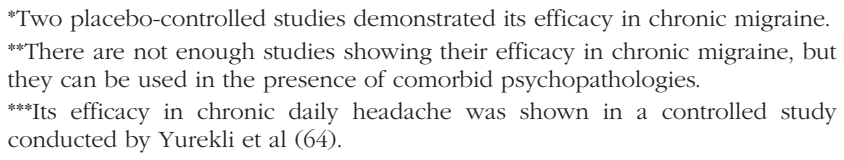 } \\
\hline
\end{tabular}


BoNT has been shown to inhibit the release of acetylcholine in the presynaptic space in the neuromuscular junction. The toxin A consists of two polypeptide chains, a heavy chain of $100 \mathrm{kD}$ and a light chain of $50 \mathrm{kD}$, which are connected to each other from the active parts by a disulfide bond. When the BoNT is injected intramuscularly, the C-terminal of the heavy chain binds specifically to the ganglioside receptor and synaptic vesicle glycoprotein-2 carriers and enters the nerve cell vesicle via endocytosis. Then the cleaved light chain passes through the vesicle into the nerve terminal cytoplasm, and cleaves SNAP-25 and syntaxin to prevent the formation of the SNARE protein complex on the membrane, which allows the neurotransmitters to bind and pass into the muscle and contract. It affects fusion proteins and inhibits acetylcholine release. This chemical denervation causes the flaccid paralysis of the muscle. The effect of BoNT is dose-dependent and reversible. Its effect starts after an average of 1 week and continues for 3-6 months. BoNT also acts in different ways in pain. Calcitonin generelated peptide (CGRP), nitric oxide and cytokines play a role in sterile neurogenic inflammation that occurs in migraine. It is estimated that toxin is acting by inhibiting neurotransmitter and neuropeptide-containing vesicles (substance P, glutamate, CGRP, calcitonin-related peptide) from the peripheral trigeminal sensory nerve terminals in pain pathways $(67,68)$. With this inhibition, it is thought that peripheral stimuli are reduced by blockade of transmission to secondary neurons, and by blocking central sensitization that is especially well defined in CM. BoNT has been shown to reduce the function of transient receptor potential vanilloid-1 in animal experiments and to affect nociception in the trigeminal ganglion (67).
Use of BoNT was evaluated in all primary headaches, but successful results were obtained only in cases with CM (69). While peripheral pathways are implicated in the etiopathogenesis of EM attacks, it is suggested that the main mechanism in CM is central sensitization and that some structural changes occur in the pathways associated with central sensitization through a similar mechanism in all neuropathic pain.

The clinical efficacy and the method/standard dose applications of BoNT with CM diagnosis started with PREEMPT trials, and the treatment previously administered with different methods and doses was accepted by many physicians after these trials. In the PREEMPT 1 and PREEMPT 2 studies published in 2010, a fixed 31-point injection of the frontal, temporal, occipital, and cervical regions was performed with 5 units (U) of BoNT per site in all patients (Figure 1) (70,71). Furthermore, 8 additional injections were given in addition to painful areas. Thus, 155-195U BoNT was applied to all patients in the study. The standard range of treatment is not clear, but our clinical practice is a one-year treatment at 3-month intervals followed by a prolongation of the duration of the treatment according to the frequency of pain.

The BOTOX preparation contains a total of $100 \mathrm{U}$ of toxin, and it is diluted with $2 \mathrm{cc}$ saline and applied at $5 \mathrm{U}$ per site. If the toxin is not to be used immediately after dilution, it can be kept in the refrigerator for 2-24 hours at maximum for 24 hours. It is recommended that all vials used or not used at the end of this period be ineffective and should be discarded. After the procedure, the patient should be observed for 10-15 minutes and the patient should be informed about possible adverse effects. The adverse effects that we often see in our daily practice are listed in Table 2. In terms of the risk of developing ptosis and weakness among
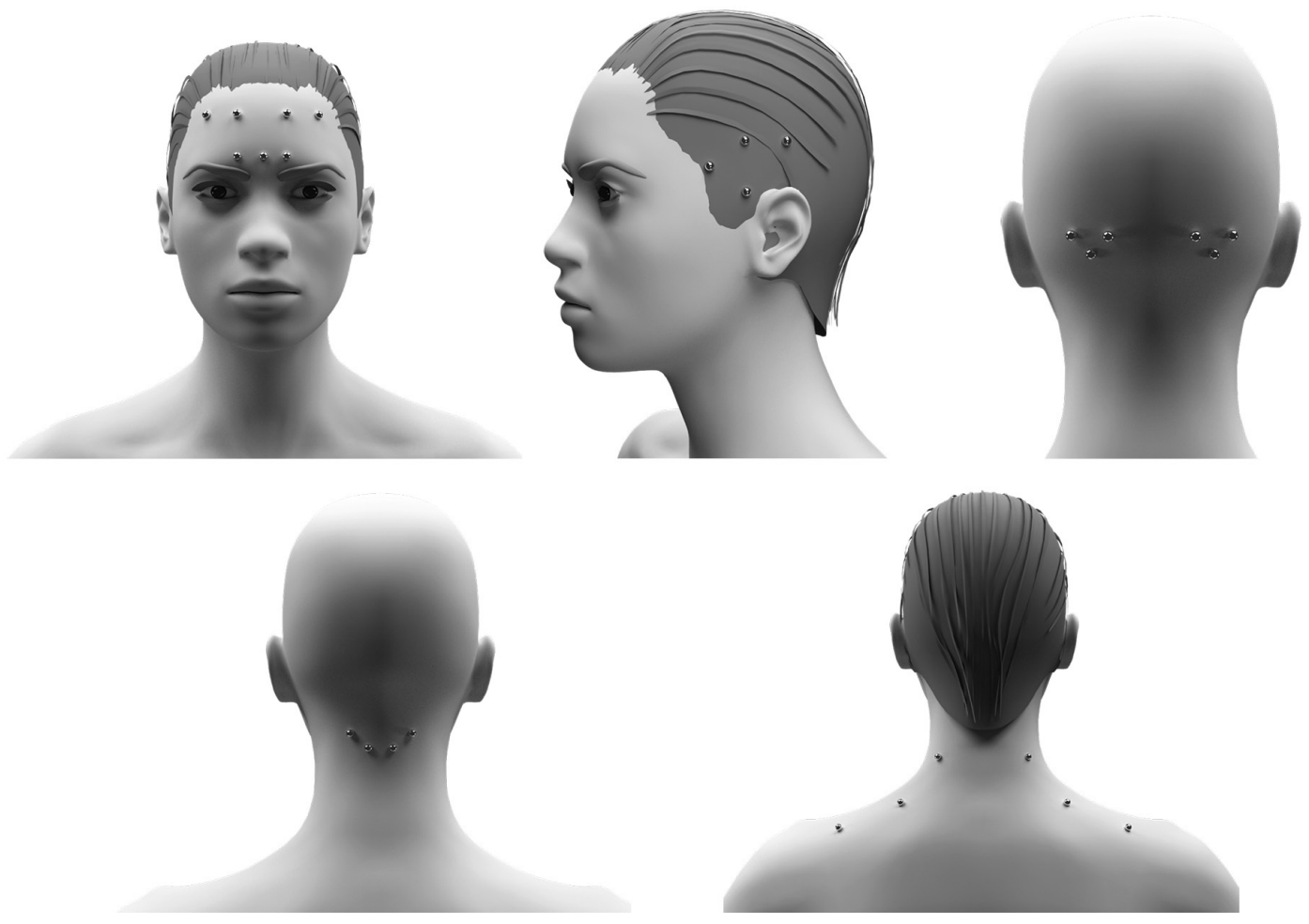

Figure 1. Botulinum toxin injection points 
these adverse effects, the injection points should be well known and should be practiced by experienced physicians (72). The reversible effect of treatment is advantageous in terms of adverse effects. BoNT administration at intervals of less than 3 months is not recommended because it may cause antibody development against toxin.

\section{Peripheral Nerve Blocks (PNBs)}

PNBs have been used for many years in refractory headache cases. In painful cases, PNBs are based on the ability of lowconcentration local anesthetics to selectively block sensory nerve fibers. Ideally, motor functions are protected or minimally affected. The duration of the activity of PNBs depends on the dose and pharmacokinetic properties of the anesthetics used. They have a longer duration of action than anticipated in clinical practice. PNBs can provide well-being for a period of weeks or months, for a longer period than the effect of the anesthetic agents. It is thought that the prolonged analgesic effect following neural block may be related to central pain modulation. Blockage of the head and neck nerves may also affect the painful syndromes in the regions outside the area innervated by these nerves. This result is often explained by the concept of "convergence" in the head and neck

\begin{tabular}{|lll|}
\hline $\begin{array}{l}\text { Table 2. Possible adverse effects of botulinum toxin } \\
\text { administration }\end{array}$ & $\begin{array}{l}\text { Incidence with } \\
\text { botulinum } \\
\text { toxin }\end{array}$ & $\begin{array}{l}\text { Incidence } \\
\text { with placebo }\end{array}$ \\
Headache & $5 \%$ & $3 \%$ \\
Ptosis & $4 \%$ & $<1 \%$ \\
Back pain & $9 \%$ & $3 \%$ \\
Musculoskeletal stiffness & $4 \%$ & $1 \%$ \\
Muscle weakness & $5.5 \%$ & $<1 \%$ \\
Myalgia & $3 \%$ & $1 \%$ \\
Pain in the injection site & $3 \%$ & $2 \%$ \\
Hypertension & $2 \%$ & $1 \%$ \\
\hline
\end{tabular}

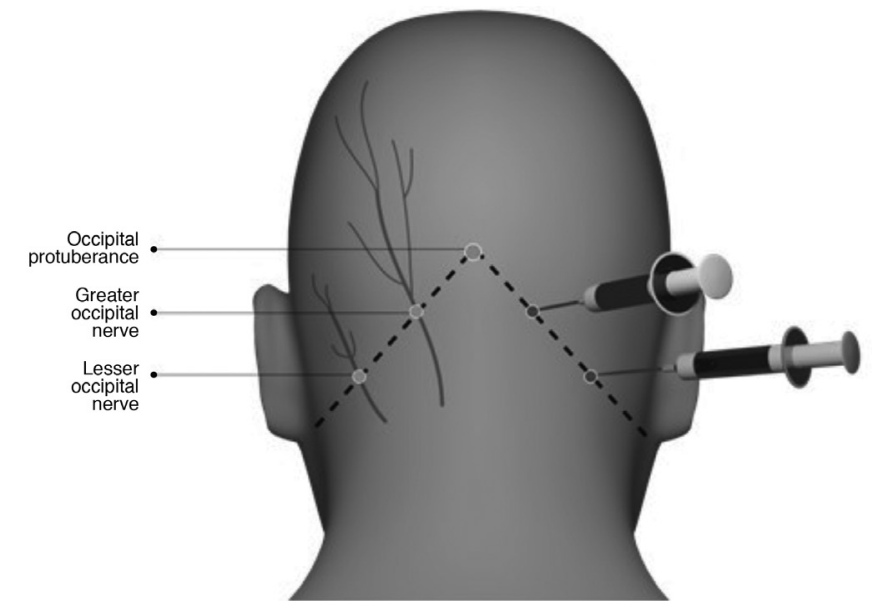

Figure 2. Greater occipital nerve blockage injection points nosociceptive system (especially between trigeminal and upper cervical sensory afferents). Unfortunately, placebo-controlled trials of PNB procedures are inadequate. In this respect, it is not yet clear what dose, time interval, and application method should be used.

\section{a) Greater Occipital Nerve (GON) Block}

PNBs have been used in the acute and prophylactic treatment of many primary headache disorders over the last 30 years. PNBs can provide well-being for a period of weeks or months in a group of patients for a longer period than the effect of the anesthetic agent. The prolonged analgesic effect following nerve block may be related to central pain modulation. Controlled studies showing the efficacy of local anesthetics cannot be performed for the immediate recognition of the anesthetic effect. The main problem here is that there is no model that can mimic the effect of local anesthetics. Local anesthetics used in daily practice are often in the amide group (lidocaine, mepivacaine, bupivacaine, and prilocaine) due to low allergy risk. There is a $1 \%$ solution of lidocaine, and the effect starts in 4-8 minutes and lasts 1-2 hours. Bupivacaine solutions $(0.25 \%-0.50 \%)$ are more effective and the effect lasts 4-8 hours. Most physicians use both molecules in combination. Although there are insufficient data on the proven efficacy, many physicians also add corticosteroid injections (often triamcolon or methylprednisolone) to treatment (73). There are insufficient data on the efficacy of the steroids, and the possible adverse effects of their addition to treatment should be known (delayed wound healing, local alopecia and skin atrophy).

The only nerve block on which controlled studies have been performed in CM treatment is GON block. In a multicenter, randomized, first placebo-controlled study published by Inan et al. (74) in 2015, GON block was shown to be effective in CM. In another study conducted in 2016, Cuadrado et al. (75) failed to demonstrate a similar effect. The effectiveness of GON block in CM treatment should be further investigated $(76,77)$.

GON block is a common practice in our clinical practice in CM. Being a minimally invasive method, its reliability, being able to be used during pregnancy and lactation, and its cost stand out as the advantages of GON block. We especially use it as the first option in our daily practice in childhood CM treatment. The technique of injection is shown in Figure 2. However, the application of BoNT in childhood cannot be performed because there are no controlled studies. In addition, other adverse effects of various pharmacologic options that may be used as prophylactic agents and the difficulties of daily drug use limit their empirical use. In this case, we think that it is very important to keep GON block in mind as a very safe option.

b) Supraorbital and Supratrochlear Nerve and Sphenopalatine Ganglion (SPG) Blocks

The supraorbital and supratrochlear nerves are the branches of the ophthalmic division of the trigeminal nerve. Their subcutaneous localizations predispose them to traumatic injury and it should be remembered in cases of headache and facial pain following head trauma. Diagnosis is only possible with the suspicion of the physician, and local anesthetic applications are the most effective methods of diagnosis and treatment. In addition, there are also numerous case studies on its use in patients with migraine, cluster headache, and short-lasting 
unilateral neuralgiform headache attacks with conjunctival injection and tearing (SUNCT). The SPG contains sensory, sympathetic, and parasympathetic autonomous fibers that join the maxillary branch of trigeminal nerve. SPG block may be performed transcutaneously or intraoral, or more easily and painlessly, from the lateral wall of the nasal cavity after topical anesthetic administration. Commercial products are available for improved application. Indications for SPG block are still not fully understood, but case reports have reported that good results are seen in patients with refractory cluster headache. There are case reports in the literature on its use in other trigeminal autonomic headaches and CM in selected cases (78).

\section{Other Invasive Methods}

Patients with refractory chronic headache can benefit from peripheral or central neurostimulation. Electrical stimulation has been investigated in various painful syndromes for many years. Non-invasive devices currently in use in the headache target supraorbital and vagus nerves (electrical stimulation) and cortex. Current invasive stimulation techniques target the occipital nerves, SPG (peripheral targets) and the ventral tegmental area. Neurostimulation treatment options can be considered as an alternative option for patients who do not want to use existing treatments and who cannot use them for various reasons (e.g., comorbidities, drug use, pregnancy) or refractory patients. The non-invasive neurostimulation device "Cefaly" was produced for transcutaneous supraorbital nerve stimulation. The device, which is connected like a headband and provides electrical stimulation at certain frequencies, is being tested in the treatment of headaches. The device has pilot studies on migraine attacks and prophylactic treatment, but the effectiveness is still not proven. Studies of deep brain stimulation and other invasive methods are more concentrated in cluster headaches $(79,80,81,82,83)$.

\section{Ethics}

Peer-review: Externally and internally peer-reviewed.

\section{Authorship Contributions}

Concept: D.U., A.Ö., A.S., Design: D.U., A.Ö., O.Ö.Y., S.D., U.U., A.S., Data Collection or Processing: A.Ö., O.Ö.Y., S.D., Analysis or Interpretation: D.U., A.Ö., O.Ö.Y., Ö.K., S.D., U.U., A.S., Literature Search: O.Ö.Y., S.D., Writing: D.U., A.Ö., O.Ö.Y., S.D., U.U., Ö.K., A.S.

Conflict of Interest: No conflict of interest was declared by the authors.

Financial Disclosure: This study is conducted as a part of Turkish Headache Database Project. Turkish Headache Database Project is supported by Turkish Neurological Society and Allergan Group INC.

\section{References}

1. Headache Classification Committee of the International Headache Society (IHS). The International Classification of Headache Disorders, 3rd ed. (beta version). Cephalalgia 2013;33:629-808.

2. Lipton RB, Silberstein SD. Episodic and chronic migraine headache: breaking down barriers to optimal treatment and prevention. Headache 2015;55:103122
3. Smitherman TA, Burch R, Sheikh H, Loder E. The prevalence, impact, and treatment of migraine and severe headaches in the United States: a review of statistics from national surveillance studies. Headache 2013;53:427436.

4. Buse DC, Manack AN, Fanning K, Serrano D, Reed ML, Turkel CC, Lipton RB. Chronic migraine prevalence, disability, and sociodemographic factors: results from the American Migraine Prevalence and Prevention Study. Headache 2012;52:1456-1470.

5. Ertas M, Baykan B, Orhan EK, Zarifoglu M, Karli N, Saip, S, Siva A. Oneyear prevalence and the impact of migraine and tension-type headache in Turkey: a nationwide home-based study in adults. Headache 2012;13:147157.

6. Murray CJ, Vos T, Lozano R, et al. Disability-adjusted life years (DALYs) for 291 diseases and injuries in 21 regions, 1990-2010: a systematic analysis for the Global Burden of Disease Study 2010. Lancet 2012;380:2197-2223.

7. Stovner LJ, Andree C. Impact of headache in Europe: a review for the Eurolight project. J Headache Pain 2008;9:139-146.

8. Stewart WF, Ricci JA, Chee E, Morganstein D, Lipton R. Lost productive time and cost due to common pain conditions in the US workforce. JAMA 2003;290:2443-2454.

9. Blumenfeld AM, Varon SF, Buse DC, Kawata AK, Manack A, Goadsby PJ, Lipton RB. Disability, HRQOL and Resource Use Among Chronic and Episodic Migraineurs: Results from the International Burden of Migraine Study (IBMS). Cephalalgia 2010;31:301-315.

10. Bigal ME, Serrano D, Reed M, Lipton RB. Chronic migraine in the population: burden, diagnosis, and satisfaction with treatment. Neurology 2008;71:559-566.

11. Giannini G, Cevoli S, Sambati L, Cortelli P. Migraine: risk factor and comorbidity. Neurol Sci 2012;33:37-41.

12. Stewart WF, Wood GC, Manack A, Varon SF, Buse DC, Lipton RB Employment and Work Impact of Chronic Migraine and Episodic Migraine. J Occup Environ Med 2010;52:8-14.

13. Negro A, D'Alonzo L, Martelletti P. Chronic migraine: comorbidities, risk factors, and rehabilitation. Intern Emerg Med 2010;5:13-19.

14. Wang SJ, Chen PK, Fuh JL. Comorbidities of migraine. Front Neurol 2010;1:1-9.

15. Antonaci F, Nappi G, Galli F, Manzoni GC, Calabresi P, Costa A. Migraine and psychiatric comorbidity: a review of Clinical findings. J Headache Pain 2011;12:115-125

16. Breslau N. Psychiatric comorbidity in migraine. Cephalalgia 1998;18:56-61.

17. Lipton RB, Hamelsky SW, Kolodner KB, Steiner TJ, Stewart WF. Migraine, quality of life, and depression: a population-based case-control study. Neurology 2000;55:629-635.

18. Zwart JA, Dyb G, Hagen K, Odegard KJ, Dahl AA, Bovim G, Stovner LJ Depression and anxiety disorders associated with headache frequency. The Nord-Trondelag health study. Eur J Neurol 2003;10:147-152.

19. Chen YC, Tang CH, Ng K, Wang SJ. Comorbidity profiles of chronic migraine sufferers in a national database in Taiwan. J Headache Pain 2012;13:311-319.

20. Ashina S, Serrano D, Lipton RB, Maizels M, Manack AN, Turkel CC, Buse DC. Depression and risk of transformation of episodic to chronic migraine. J Headache Pain 2012;13:615-624.

21. Juang KD, Wang SJ, Fuh JL, Lu SR, Su TO. Comorbidity of depressive and anxiety disorders in chronic daily headache and its subtypes. Headache 2000;40:818-823.

22. Breslau N. Psychiatric comorbidity in migraine. Cephalalgia 1998;18:56-61.

23. McWilliams LA, Goodwin RD, Cox BJ (2004). Depression and anxiety associated with three pain conditions: results from a nationally representative sample. Pain 2004;111:77-83.

24. Lucchetti G, Peres MF, Lucchetti AL, Mercante VP, Gunedler VZ, Zukerman E. Generalized anxiety disorder, subthreshold anxiety and anxiety symptoms in primary headache. Psychiatry Clin Neurosci 2013;67:41-49.

25. Breslau N, Davis GC, Andreski P. Migraine, psychiatric disorders, and suicide attempts: an epidemiologic study of young adults. Psychiatry Res 1991;37:11-23.

26. Peterlin BL, Tietjen G, Meng S, Lidicker J, Bigal M. Posttraumatic stress disorder in episodic and chronic migraine. Headache 2008; $48: 517-522$. 
27. Minen MT, De Dhaem OB, Van Diest AK, Powers S, Schwedt TJ, Lipton R, Silbersweig D. Migraine and its psychiatric comorbidities. J Neurol Neurosurg Psychiatry 2016;87:741-749.

28. Tietjen GE, Brandes JL, Peterlin BL, Eloff A, Dafer RM, Stein MR, Drexler E, Martin VT, Hutchinson S, Aurora SK, Recober A, Herial NA, Utley C, White L, Khuder SA. Childhood maltreatment and migraine (part I) Prevalence and adult revictimization: a multicenter headache clinic survey. Headache 2010;50:20-31

29. Sancisi E, Cevoli S, Vignatelli L, Nicodemo M, Pierangeli G, Zanigni S, Grimaldi D, Cortelli P, Montagna P. Increased prevalence of sleep disorders in chronic headache: a case-control study. Headache 2010;50:1464-1472.

30. Kelman L, Rains JC. Headache and sleep: examination of sleep patterns and complaints in a large clinical sample of migraineurs. Headache 2005;45:904-910.

31. Calhoun AH, Ford S. Behavioral sleep modiŞcation may revert transformed migraine to episodic migraine. Headache 2007;47:1178-1183.

32. Karaali-Savrun F, Göksan B, Yeni SN, Ertan S, Uzun N. Seizure-related headache in patients with epilepsy. Seizure 2012;11:67-69.

33. Marks DA, Ehrenberg BL. Migraine-related seizures in adults with epilepsy, with EEG correlation. Neurology 1993;43:2476-2483.

34. Kurth T, Gaziano JM, Cook NR, Logroscino G, Diener HC, Buring JE. Migraine and risk of cardiovascular disease in women. JAMA 2006;296:283-291.

35. Kruit MC, van Buchem MA, Hofman PAM Bakkers JT, Terwindt GM, Ferrari MD, Launer LJ. Migraine as a risk factor for subclinical brain lesions. JAMA 2004;291:427-434.

36. Schürks M, Rist PM, Bigal ME, Buring JE, Lipton RB, Kurth T. Migraine and cardiovascular disease: systematic review and meta-analysis. BMJ 2009;339:3914.

37. Bigal ME, Kurth T, Santanello N, Buse D, Golden W, Robbins M, Lipton RB. Migraine and cardiovascular disease: a population-based study. Neurology 2010;74:628-635

38. Katsarava Z, Manack A, Yoon MS, Obermann M, Becker H, Dommes P, Turkel C, Lipton RB, Diener HC. Chronic migraine: classiŞcation and comparisons. Cephalalgia 2011;31:520-529.

39. Bigal ME. Migraine and cardiovascular disease. Arq Neuropsiquiatr 2011;69:122-129.

40. Kruit MC, Launer LJ, Ferrari MD, van Buchem MA. Infarcts in the posterior circulation territory in migraine. The population-based MRI CAMERA study. Brain 2005;128:2068-2077.

41. Scher AI, Gudmundsson LS, Sigurdsson S, Ghambaryan A, Aspelund T, Eiriksdottir G, van Buchem MA, Gudnason V, Launer LJ. Migraine headache in middle age and late-life brain infarcts. JAMA 2009;301:2563-2570.

42. Rose KM, Carson AP, Sanford CP, Stang PE, Brown CA, Folsom AR, Szklo M. Migraine and other headaches: associations with Rose angina and coronary heart disease. Neurology 2004;63:2233-2239.

43. Scher AI, Terwindt GM, Verschuren WM, Kruit MC, Blom HJ, Kowa H, Frants RR, van den Maagdenberg AM, van Buchem M, Ferrari MD, Launer LJ. Migraine and MTHFR C677T genotype in a population-based sample. Ann Neurol 2006;59:372-375.

44. Anzola GP, Magoni MD, Guindani M, Rozzini L, Dalla Volta GD. Potential source of cerebral embolism in migraine with aura. A transcranial Doppler study. Neurology 1999;52:1622-1625.

45. Schwerzmann M, Nedeltchev K, Lagger F, Mattle HP, Windecker S, Meier B, Seiler C. Prevalence and size of directly detected patent foramen ovale in migraine with aura. Neurology 2005;65:1415-1418.

46. Hagen K, Einarsen C, Zwart JA, Svebak S, Bovim G. The co-occurrence of headache and musculoskeletal symptoms amongst 51,050 adults in Norway. Eur J Neurol 2002;9:527-533.

47. Maizels M, Aurora S, Heinricher M. Beyond neurovascular: migraine as a dysfunctional neurolimbic pain network. Headache 2012;52:1553-1565.

48. Evans RW, de Tommaso M. Migraine and Fibromyalgia. Headache 2011;51:195-299.

49. Özge A, Öksüz N, Ayta S, Uluduz D, Yıldırım V, Toros F, Taşdelen B. Atopic disorders are more common in childhood migraine and correlated headache phenotype. Pediatr Int 2014;56:868-872

50. Cole JA, Rothman KJ, Cabral HJ, Zhang Y, Farraye FA. Migraine, fibromyalgia, and depression among people with IBS: a prevalence study. BMC Gastroenterol 2006;6:26.
51. Alehan F, Ozçay F, Erol I, Canan O, Cemil T. Increased risk for coeliac disease in paediatric patients with migraine. Cephalalgia 2008;28:945-949.

52. Stuginski-Barbosa J, Macedo HR, Bigal ME, Speciali JG. Signs of temporomandibular disorders in migraine patients: a prospective, controlled study. Clin J Pain 2010;26:418-421.

53. Goncalves DA, Camparis CM, Speciali JG, Franco AL, Castanharo SM, Bigal ME. Temporomandibular disorders are differentially associated with headache diagnoses: a controlled study. Clin J Pain 2011;27:611-615.

54. Cho SJ, Chu MK. Risk factors of chronic daily headache or chronic migraine. Curr Pain Headache Rep 2015;19:465.

55. Scher AI, Bigal ME, Lipton RB. Comorbidity of migraine. Cur Opin Neurol 2005;18:305-310.

56. Rains JC, Poceta JS. Sleep and headache. Curr Treat Options Neurol 2010;12:1-15.

57. Pistoia F, Sacco S, Carolei A. Behavioral therapy for chronic migraine. Curr Pain Headache Rep 2013;17:1-8.

58. Sun-Edelstein C, Mauskop A. Alternative headache treatments: nutraceuticals, behavioral and physical treatments. Headache 2011;51:469-483.

59. Harris P, Loveman E, Clegg A, Easton S, Berry N. Systematic review of cognitive behavioural therapy for the management of headaches and migraines in adults. Br J Pain 2015;9:213-224.

60. Silberstein SD, Lipton RB, Dodick DW, Freitag FG, Ramadan N, Mathew N, Jordan DM. Topiramate Chronic Migraine Study Group Efficacy and safety of topiramate for the treatment of chronic migraine: a randomized, double-blind, placebo-controlled trial. Headache 2007;47:170-180.

61. Diener HC, Bussone G, Van Oene JC, Lahaye M, Schwalen S, Goadsby PJ. Topiramate reduces headache days in chronic migraine: a randomized double-blind, placebo-controlled study. Cephalalgia 2007;27:814-823.

62. Silvestrini M, Bartolini M, Coccia M, Baruffaldi R, Taffi R, Provinciali L Topiramate in the treatment of chronic migraine. Cephalalgia 2003;23:820-824.

63. Edvardsson, B. Atenolol in the prophylaxis of chronic migraine: a 3-month open-label study. Springerplus 2013;2:479.

64. Yurekli VA, Akhan G, Kutluhan S, Uzar E, Koyuncuoglu HR, Gultekin F The effect of sodium valproate on chronic daily headache and its subgroups. J Headache Pain 2008;9:37-41.

65. Banzi R, Cusi C, Randazzo C, Sterzi R, Tedesco D, Moja L. Selective serotonin reuptake inhibitors (SSRIs) and serotonin-norepinephrine reuptake inhibitors (SNRIs) for the prevention of migraine in adults. Cochrane Database Syst Rev 2015;4:CD002919.

66. Banzi R, Cusi C, Randazzo C, Sterzi R, Tedesco D, Moja L. Selective serotonin reuptake inhibitors (SSRIs) and serotonin-norepinephrine reuptake inhibitors (SNRIs) for the prevention of tension-type headache in adults Cochrane Database Syst Rev 2015;4:CD011681.

67. Gazerani P, Staahl C, Drewes AM, Arendt-Nielsen L. The effects of botulinum toxin type $\mathrm{A}$ on capsaicin-evoked pain, flare, and secondary hyperalgesia in an experimental human model of trigeminal sensitization. Pain 2006;122:315325.

68. Aoki KR. Review of a proposed mechanism for the antinociceptive action of botulinum toxin type A. Neurotoxicology 2005;26:785-793.

69. Ashkenazi A, Blumenfeld A. OnabotulinumtoxinA for the treatment of headache. Headache 2013;53:54-61.

70. Aurora SK, Dodick DW, Turkel CC, DeGryse RE, Silberstein SD, Lipton $\mathrm{RB}$, Brin MF. OnabotulinumtoxinA for treatment of chronic migraine: results from the double-blind, randomized, placebo-controlled phase of the PREEMPT 1 trial. Cephalalgia 2010;30:793-803.

71. Diener HC, Dodick DW, Aurora SK, Turkel CC, DeGryse RE, Lipton $\mathrm{RB}$, Brin MF. OnabotulinumtoxinA for treatment of chronic migraine: results from the double-blind, randomized, placebo-controlled phase of the PREEMPT 2 trial. Cephalalgia 2010;30:804-814.

72. Dodick DW, Turkel CC, DeGryse RE, Aurora SK, Silberstein SD, Lipton RB, Brin MF. OnabotulinumtoxinA for treatment of chronic migraine: pooled results from the double-blind, randomized, placebo-controlled phases of the PREEMPT clinical program. Headache 2010;50:921-936.

73. Palamar D, Uluduz D, Saip S, Erden G. Ultrasound-guided greater occipital nerve block: an efficient technique in chronic refractory migraine without aura?. Pain Physician 2015;18:153-162. 
74. Inan LE, Inan N, Karadaş Ö, Gül HL, Erdemoğlu AK, Türkel Y, Akyol A. Greater occipital nerve blockade for the treatment of chronic migraine: randomized, multicenter, double-blind, and placebo-controlled study. Acta Neurologica Scandinavica 2015;132:270-277.

75. Cuadrado ML, Aledo-SerranoÁ, Navarro P, López-Ruiz P, Fernández-de-lasPeñas C, González-Suárez, Fernández-Pérez, C. Short-term effects of greate occipital nerve blocks in chronic migraine: A double-blind, randomised, placebo-controlled clinical trial. Cephalalgia 2017;37:864-872.

76. Solomon S. Greater occipital nerve blocks as migraine therapy: A discussion of two recent randomized, double-blinded, placebo-controlled clinical trials. Cephalalgia 2016;36:1094.

77. Blumenfeld A, Ashkenazi A, Napchan U, Bender S, Klein BC, Berliner R, Ailani J, Schim J, Friedman DI, Charleston L, Young WB, Robertson CE, Dodick DW, Silberstein SD, Robbins MS. Expert consensus recommendation fort he performance of peripheral nevre blocks for headaches- a narrative review. Headache 2013;53:437-446.

78. Dach F, Eckeli AL, Ferreira K, Speciali JG. Nerve block fort he treatment of headaches and cranial neuralgias-a practical approach. Headache 2015;55:59-71.
79. Dodick DW, Silberstein SD, Reed KL, Deer TR, Slavin KV, Huh B, Ordia J, Vaisman J, Goldstein J, Mekhail N. Safety and efficacy of peripheral nerve stimulation of the occipital nerves for the management of chronic migraine: long-term results from a randomized, multicenter, double-blinded, controlled study. Cephalalgia 2015;35:344-358.

80. Leone M, Franzini A, Bussone G. Stereotactic stimulation of posterior hypothalamic gray matter in a patient with intractable cluster headache. $\mathrm{N}$ Engl J Med 2001;345:1428-1429.

81. Magis D, Schoenen J. Advances and challenges in neurostimulation for headaches. Lancet Neurol 2012;11:708-719.

82. May A, Bahra A, Büchel C, Frackowiak RS, Goadsby PJ. Hypothalamic activation in cluster headache attacks. Lancet 1998;352:275-278.

83. Schoenen J, Jensen RH, Lanteri-Minet M, Láinez MJ, Gaul C, Goodman AM, Caparso A, May A. Stimulation of the sphenopalatine ganglion (SPG) for cluster headache treatment. Pathway $\mathrm{CH}-1$ : a randomized, sham-controlled study. Cephalalgia 2013;33:816-830. 